\title{
Organizational culture in the human resource of a mexican hotel organization
}

\section{La cultura organizacional en el recurso humano de una organización hotelera mexicana}

PÉREZ-MAYO, Augusto Renato*†

Universidad Autónoma del Estado de Morelos, Mexico.

ID $1^{\text {st }}$ Author: Augusto Renato, Pérez-Mayo / ORC ID: 0000-0003-1094-3283, Researcher ID Thomson: B-4276-2016, SNI CONACYT ID: 239558

\begin{abstract}
This document describes the organizational culture factor of the human resource that works in a Mexican hotel organization. The theoretical path was made from the inputs of Barney, Hill, Pérez Mayo, Gordon, Thévenet, Golden, Stoner, Serna, Koontz y Cooke y Lafferty; as a explanatory framework which distinguishes the importance of identifying through an inventory of organizational culture, as it builds and defines such organization, it's relations and it's processes. The methodology is empirical, descriptive and quantitative. The instrument used for the collection of data was the questionary generated by Cooke and Lafferty, called Inventory of Organizational Culture. This instrument allowed to identify the Organizational Culture starting from the methodological categorical criteria proposed by themselves, meaning, they measured the dimensions: realization, auto-update, humanistic-encouraging, affiliate, conventional, approval, dependent, of evasion, antagonistic, power, competitive and perfectionist; defined by the instrument.
\end{abstract}

Culture, organizational culture, hotel

\begin{abstract}
Resumen
La obsolescencia programada surgió de la necesidad de mantener una El artículo revisa la cultura organizacional del recurso humano que trabaja en una organización hotelera de México; la ruta teórica realizada es bajo la mirada de Barney, Hill, Pérez Mayo, Gordon, Thévenet, Golden, Stoner, Serna, Koontz y Cooke y Lafferty (1989) como marco explicativo que destaca la importancia de identificar a través de un inventario de cultura organizacional del cómo se construye y define dicha organización, sus relaciones y procesos. La metodología es empírica, descriptiva y cuantitativa. El instrumento utilizado para la recolección de datos fue el cuestionario generado por el Cooke y Lafferty, denominado Inventario de Cultura Organizacional. Este instrumento permitió identificar la cultura organizacional a partir de los criterios categoriales metodológicos propuestos por ellos mismos, es decir se midieron la dimensión: realización, autoactualización, humanístico-alentador, afiliativo, convencional, aprobación, dependiente, de evasión, antagónico, poder, competitivo y perfeccionista
\end{abstract}

Cultura, Cultura organizacional, Hotel

Citation: PÉREZ-MAYO, Augusto Renato. Organizational culture in the human resource of a mexican hotel organization. Journal-Labor and Demographic economic. 2020. 4-6:22-27.

\footnotetext{
* Correspondence to Author (Email: renatomayo@hotmail.com)

$\dagger$ Researcher contributing first author.
} 


\section{Introduction}

Studying culture in organizations has a high degree of importance within the organizational environment, due to the influence it has on the behavior of employees. Its diagnosis is fundamental. The existence of an adequate or optimal organizational culture has a positive impact on the performance of employees and the organization in general. Therefore, studying the culture in a public or private organization and whether it serves the decision making of the top management is decisive, to directly influence the service provided to the clients. In a hotel, strategies, policies, objectives, and goals should focus on customer service that is satisfactory. The most important point in any organization that is dedicated to lodging service, is to know just what kind of service culture it provides. In other words, the organizational culture is a set of beliefs, values and norms that are specific behavioral expectations imbued in the organization, which are not simply written down in a manual that must be known to improve. (Manucci, 2010).

\section{Literature review}

Amid the accumulation of research efforts deployed, trying to prove and specify the true relationship between organizations and the environment in which they operate, the concept of culture has been incessantly linked to the study of organizations. Trying to understand the relationship between organizational culture and performance, Barney (1986) describes organizational culture as a complex set of values, beliefs, assumptions, and symbols. It is considered an unusual competitive advantage by which the organization/company can be perceived in a totally different way with respect to its competitors, consequently generating a certain type of differentiation (Hill, 1988) with respect to its customers.

Having transferred the concept of culture to organizations, as a differentiating element of their internal life of how to face their own challenges in a diverse and complex environment of permanent change, his study becomes essential. This, from the point of view of trying to understand the impact that the organizational culture has had, in the achievement of the economic and social objectives of the organizations that, have built strong and successful cultures.
Pérez Mayo (2017) suggests that the peculiarity and specificity of human beings in organizations must be understood, and this leads to the study of culture within organizations.

Although there are many characteristics in the organizational culture, it is important to note that it is "based on beliefs that are internally oriented to how to manage and externally to how to compete" (Gordon, 1991). It means that the culture is transformed in a conscious or unconscious way, as a way to face the evident paradox of the organizations, to find a balance between their adaptation to the environment; in which they develop responding to its pressures and demands, and the need to maintain an internal cohesion of all its operation system (Thévenet, 1986).

The concept of organizational culture arises, because many authors try to know the organization in depth and not only superficially, hence the overpopulation of the concept. Golden (1992), defines organizational culture as "an interpretative, historically developed and socially maintained scheme that team members use to give meaning and structure their own actions and those of others", Stoner and other authors (1984), define organizational culture as "the set of important understandings as the norms, attitudes and beliefs shared by all members of the organization" (Stoner et al. 1996 in Nicolini \& Parodi, 2015).

Serna (2003), points out that "each organization has its own culture, different from the others, which gives it its identity"; which affirms that "the culture of an institution is the way in which the organizations do things, how they establish properties and give importance to the different business tasks, besides including what is important for the company" (Rendón, 2004). Koontz (2007), refers to it as "general model of conduct, ideas and values shared by its members and inferred from what people say, what they do and what they think in an organizational environment" (González, 2012). Most authors agree that culture is shared and learned by all members of the organization. 
The administrative literature on organizational culture emphasizes that: first, the organizational culture is associated in an important way with the result of the work; second, that the contents or particular characteristics of an organizational culture explain this association; and third, that a change in the result of the work can be achieved by changing the particular contents of the organizational culture (Aguilar Edwards, 2006, p. 3)

The organizational culture has been measured by instruments that bring together the main characteristics of the organization. One of them is Cooke and Lafferty's (1989) Organizational Culture Inventory, which has a fully human orientation, reflecting perceived support, cooperation, mutual respect, and consideration, as dimensions.

Cooke and Lafferty's model provides an image of the organization's culture, based on the norms of human resource behavior in organizations. It focuses on the behavioral patterns that members believe are necessary to fit and meet expectations within their organization. There are 12 types of behavioral patterns, which are organized in three general dimensions; they are distinguished between:

Constructive culture: Its members are encouraged to interact with people and approach tasks in ways that help them meet their needs. It has 4 subgroups: Accomplishment, self-actualization, humanist-encouragement, and affiliation.

Passive/Defensive Culture: Its members believe that they should interact with people in a way that does not endanger their own safety. It has 4 subgroups: approval, conventional, dependent and avoidance.

Aggressive/Defensive Culture: Its members seek to approach the task in forceful ways to protect their status and safety. It has 4 subgroups: antagonistic, power, competitive and perfectionist.

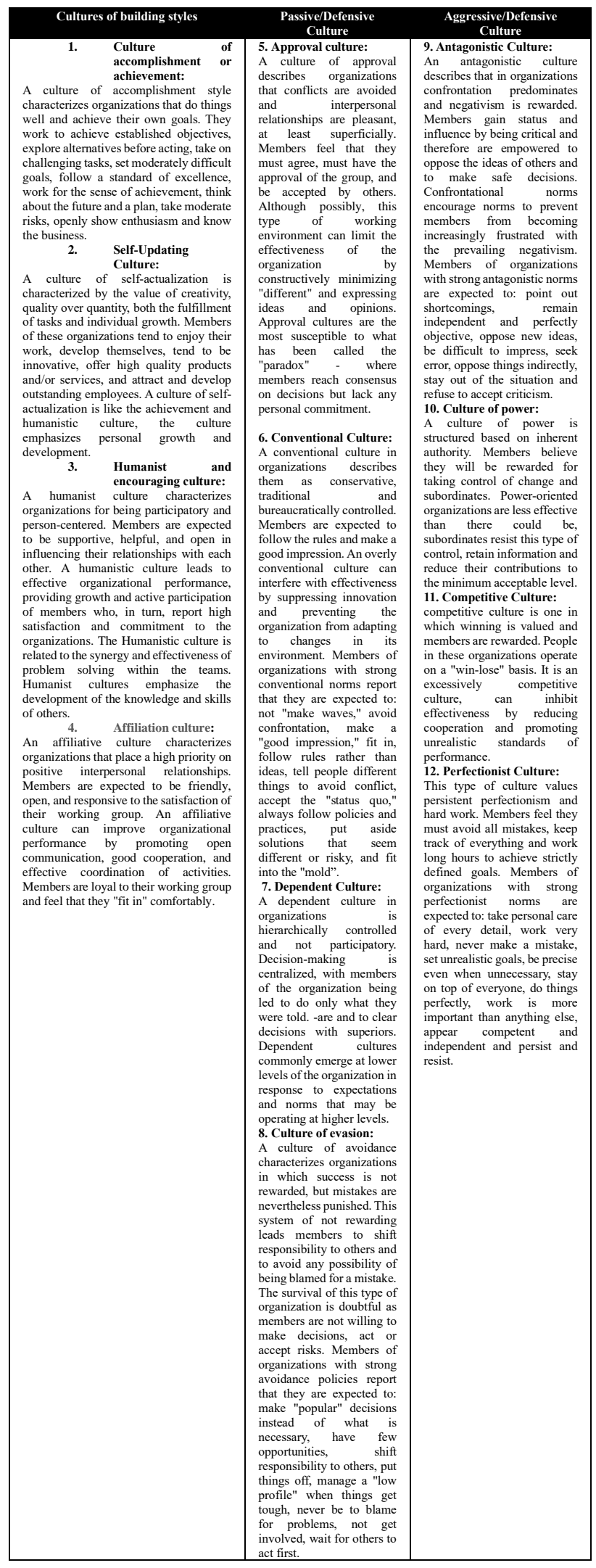

Table 1 Types of culture and their characteristics Source: Elaborated from the reading of Organizational Culture Inventory (Cooke and Lafferty, 1989) 


\section{Description of the method}

This research comprises a descriptive study with a quantitative approach. In this sense, "descriptive studies seek to specify the properties, characteristics and profiles of people, groups, communities, processes, objects or any other phenomenon that is subject to analysis", "in quantitative studies their purpose is to measure independently or jointly the variables that will allow evidence of the study of the phenomenon in particular and establish the relationships" (Hernández, 2014). The aim of this research is precisely to describe the dominant culture of an organization in Mexico. This information will make it possible to determine what aspects of its culture are. The Organizational Culture Inventory (OCI; Cooke \& Lafferty, 1987) was used, which is a quantitative instrument by Cooke and Lafferty. The design of this research can be defined as non-experimental. "Non-experimental research is observing phenomena as they occur in their natural context, and then analyzing them" (Hernández, 2014). The data collection for this study was cross-sectional since the data collection was in a limited time. The sample to be considered for this study is 73 hotel employees, $100 \%$ of whom are employees.

\section{Results}

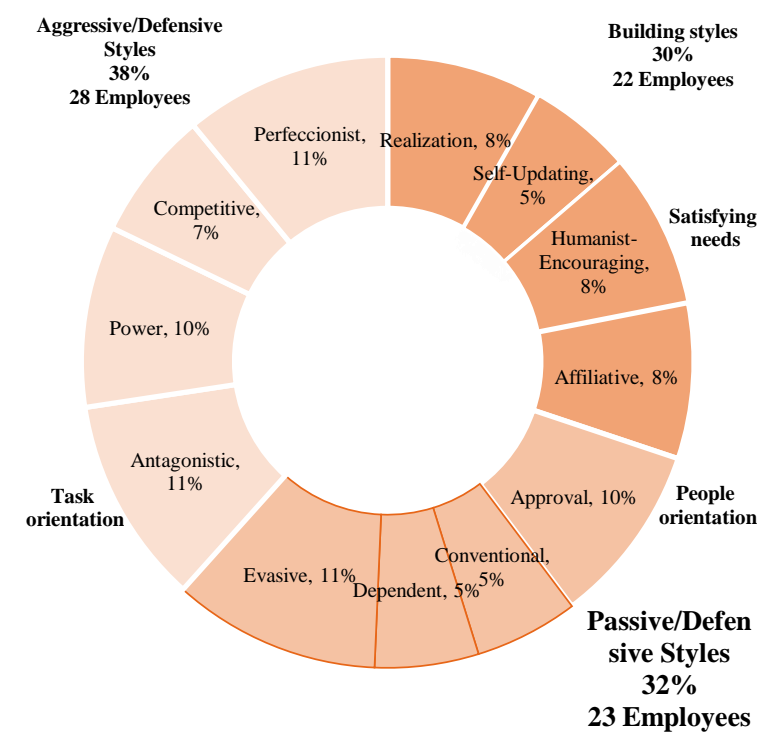

Graphic 1 Results of the application of the instrument Source: Prepared based on the application of the tool using the model by Cooke and Lafferty (2013, pp. 149150), based on the graph resulting from the use of Human Synergistics International software
The results of the instrument applied are very similar to those of other investigations in Mexico, that is, not necessarily unfavorable, although the highest percentage is of aggressive/defensive style $38 \%$ ( 1 and 8 of the configuration of the measurement table of Cooke and Lafferty), which are of opposition, perfectionist, antagonistic styles, retain the information and reduce their contributions to the minimum acceptable level, besides being competitive, it is a real opportunity for organizational intervention. The hotel is a service company, where the most important thing is the guests and the service they receive, they cannot be the majority of workers of this style, but they must worry about giving a friendly service not so square or perfect. Being such a perfectionist can cause members to get lost in the shuffle and get lost in the details.

A proportional relationship is found with the styles of competition and performance or (achievement) where both styles tend to follow the activities. A point in favor of hotel organization is that competitiveness is moderate and that is motivating for hotel members as they focus on always being the best, which makes them seek to achieve good feedback from guests in order to access existing stimulus packages. Another finding is that we find a relationship between these three styles of culture: perfectionist, power and antagonistic. Similar results to those found by Velasco Ocampo in his thesis to obtain the Master's degree in Organization Administration (Velasco Ocampo, 2017).

The next two organizational culture styles, passive/defensive and constructivist, are almost the same percentage, which is the other half of the hotel's employees. Although the passive/defensive style is $1 \%$ more (32\%), which does not say that they are evasive, dependent, conventional and approving, although they tend to be more evasive, this is not very good since they do not get involved in the hotel projects or pass the responsibility of the work to the most, they do not make decisions and this is bad since many times they must know how to make decisions at the moment with each guest. 
Unfortunately, many of these cultural surrogates promote the norms for the defensive. And the behavior ultimately has negative effects on members and the organization. This style of culture disconnects evades, puts on the defensive the bad attribution of success and this highlights the importance of alignment. We find cultural disconnections in the same dimensions of analysis and this suggests that this organization needs to align its missions and objectives with shared values and assumptions, and then make appropriate changes or improvements in its systems, structures, technologies and member skills. On the other hand, finding approval style employees is very good, as they always look to be approved by others, which means they look for guests to accept them. There is a proportional relationship between approval and conventional organizational culture style since conventional ones are conservative, traditional, and bureaucratically controlled. Members are expected to follow the rules and make a good impression. The last style of organizational culture according to the results in percentage is the constructivist (30\%), within this style are the: affiliative, humanist-encouraging, selfactualization and realization. In it we can see that there is a correlation between humanistencouraging and affiliative because they tend to know how to listen to the needs of themselves, help others, take their time with customers, caring for them and at the same time have tact with customers, are friendly consider people as the most important, know how to have good relationships with others, this correlation is very good because in the hotel almost all employees have direct contact with guests always and the objective of the hotel is to achieve customer satisfaction.

\section{Conclusions and recommendations}

The organization must seek to increase the constructive style of its organizational culture to achieve the objectives since, according to the theory of Cooke and Lafferty is the best style for optimal performance in the organization. It is also necessary to lower the percentages of the aggressive/defensive and passive/defensive styles because it is a service organization.
The implementation of an intervention program is recommended to implement the constructive style because they are the ones that are more oriented to the human being and his relations, since in the hotel there is always direct contact with the guests and these are the main objective of the organization for the construction of the fidelity with the organization.

With this program of intervention of the organizational culture the percentage of passive/defensive style would be lowered since they do not like to get involved with the activities if they do not feel safe, protected or comfortable, this can cause that when there are changes in the procedures they get involved late this may not achieve the objectives or goals of those changes due to lack of time and because in the hotel sector it is very important that the employees are active and friendly to meet the different needs of each guest, which can help the guests leave satisfied with the service. Also impacting the program would be the percentage of the aggressive/defensive style that resulted in a very high percentage because they always seek to approach activities in an aggressive or antagonistic manner which is bad because they cannot attend guests in an aggressive manner. In the hotel the most important thing is the service towards the guests and as each guest is different, they cannot treat the guests in the same way they cannot be perfect. In the end, there are 3 styles of culture in the organization: Constructive culture, passive/defensive culture, and aggressive/defensive culture, more or less but coexist. Strategically managing a culture requires not only the clarification of visions and values, but also the identification of hints (and unanticipated consequences).

\section{References}

Aguilar Edwards, A. (2006). El diagnóstico de "La" cultura organizacional o las culturas de la cultura. Global Media Journal, 3(6), 1-11. https://www.redalyc.org/articulo.oa?id=687306 12

Barney, J. B. (1986). Organizational Culture: Can It Be a Source of Sustained Competitive Advantage? Academy of Management Review, 11(3), 656-665. https://doi.org/10.5465/amr.1986.4306261 
Cooke, R.A., \& Lafferty, J.C. (1989). Organizational Culture Inventory, Plymouth: Human Synergistics.

Fernández, N., \& Bringmann, E. (2007). El impacto de la cultura organizacional y del liderazgo en las empresas familiares. Conocimiento, Innovación y Emprendedores: camino al futuro. Logroño: Universidad de la Rioja, 3428-3444.

Fernández, Tabaré (2004) Clima organizacional en las escuelas: un enfoque comparativo para México y Uruguay, Revista electrónica iberoamericana sobre calidad, eficacia y cambio en educación, 2(2).

Gordon, G. G. (1991). Industry determinants of organizational culture. Academy of management review, 16(2), 396-415.

González Salinas, R. C., \& Blanco Jiménez, M. (2012). Revisión teórica de los factores culturales organizacionales y psicosociales para una implantación exitosa de empresas extranjeras en México. InnOvaciOnes de NegOciOs, 9(17), 129-148. https://core.ac.uk/download/pdf/84812959.pdf

Hernández Sampieri, R. (2014) Metodología de la Investigación. $6^{\text {a }}$, edición, México, DF.

Aguilar, J. A. H. Aplicación de la minería de datos para la toma de decisiones: El Caso de la cultura organizacional en una tienda del IMSS (Doctoral dissertation, Universidad Autónoma del Estado de Morelos).

Hill, C. W. (1988). Differentiation versus low cost or differentiation and low cost: A contingency framework. Academy of management Review, 13(3), 401-412.

Stoner, J. A. F., Freeman, R. E., \& Gilbert, D. R. (1996). Administración. Pearson educación.

Manucci, M. (2010). Contingencias: 5 desafíos de cambio para una nueva década (No. 658.012. 2). Grupo Editorial Norma.

Nicolini, C., \& Parodi, J. (2015). Comunicación interna en la Administración Pública española: Claves para innovar. INAP.
Pérez Mayo, A. R. (2017). El aprendizaje de lo humano. Una aproximación transdisciplinar para el conocimiento de las organizaciones. En A. R. Pérez Mayo \& L. S. Vallejo Trujillo (Eds.), Organización y la Teoría Organizacional. Una Visión transdisciplinaria entre Cuerpos Académicos (pp. 21-50). UAEM-Bonilla Artigas Editores.

Rendón Cobián, M., \& Montaño Hirose, L. (2004). Las aproximaciones organizacionales. Caracterización, objeto y problemática. Contaduría y Administración, (213),1-15. ISSN: 0186-1042. Disponible en: https://www.redalyc.org/articulo.oa?id=395/39 521305

Garay, R. R. (2009). La cultura organizacional. Un potencial activo estratégico desde la perspectiva de la administración. Invenio, 12(22), 67-92.

Rodriguez M., Dario (2005). Diagnóstico de la cultura organizacional pp. $136-157$, en Diagnóstico organizacional. México D.F. Thévenet, M., \& Chevalier, A. (1986). Audit de la culture d'entreprise. Editions d'Organisation.

Velasco Ocampo A. (2015) Estudio Empírico de la Cultura Organizacional según J. Clayton Lafferty en la Empresa Hotelera. Caso: Hotel Barceló de Cuernavaca. Tesis de la Maestría en Administración de Organizaciones UAEM. 